Vol. 4 No. 2, December 2021, pp. 133-144

\title{
English Language Variation of Tourist Guide: A Case Study of Indonesian Context
}

\author{
Fhadli Noer ${ }^{1}$, Zul Astri' ${ }^{2}$, Nurul Hidjrah Hairuddin ${ }^{3}$ \\ 1) Institut Teknologi dan Kesehatan Permata IImu Maros \\ 2) Universitas Muslim Maros \\ 3) Politeknik Negeri Ujung Pandang \\ 1) noerfhadli@gmail.com \\ 2) zulastri17@gmail.com \\ 3) nurulhidjrahh@poliupg.ac.id
}

\begin{abstract}
Individuals frequently speak English differently depending on their native language or the society they live in. A primary goal of our research is to learn more about the unique linguistic characteristics of the Indonesian people. This study aims to discover the language variation of English used by Indonesian tourist guides. Researchers used library and field research to perform the analysis. The researcher gathered data by recording, transcribing, and categorizing it in three separate processes. Furthermore, the researchers utilized a descriptive qualitative method to examine the usual linguistic features of English used by the tour guide. According to the findings of this study, the code choice of the three tour guides is relatively comparable. They used some particular lexical, namely actually, so, this is I and 'and then' In addition, they perform code-switching and code-mixing.
\end{abstract}

Keywords: English, Language Variation, Tourist, Guide, Indonesia

\section{INTRODUCTION}

Humans simply cannot exist without language. It is a means of conveying ideas, thoughts, feelings, and anything else that humans may think of. As stated by Kridalaksana in Mulyadi (2009: 2), the system of sound symbols employed by society for cooperation, interaction, and self-identification is a system of arbitrary sound symbols. A person's ability to communicate with another person through a combination of verbal and nonverbal means is called language.
It is broadly agreed that no one in the world can live independently, even if he has everything necessary for survival. He requires the company of other people, either as friends or as members of society, to share his feelings or even solve their problems. All of these are possible just through the use of a language.

Today, an increasing number of people speak English as a second language. It is also the language of the Americans, Canadians, and Australians. (Kisno , 2011 :34). Additionally, Singaporeans, Hong Kong residents, Taiwanese, 
and even Indonesians speak it. They all speak the same language, English, but we refer to them by their dialects, including English, American, Canadian, Australian, Singaporean, and Hong Kong dialects.

No one can deny that English has become a global language. (Kisno 2011 :34). People can think more clearly when they use this language. To be a successful student in a foreign country, one must grasp international community interaction. So the question is, "as a student of the English language in Indonesia, which English dialect must we study?

The initial question is that we must study English using a received pronunciation (RP) (Kisno, 2011: 35). Speaking it to all English idiolect and dialect speakers is stable (Kisno. 2011:35). If we speak English with the received pronunciation, we can ensure that all English speakers understand us. English is highly variable due to the variety of factors affecting this situation. Individuals speak English with slight variations that their native tongue or local culture influence. As a result, this study seeks to ascertain the linguistic characteristics of the Indonesian people.

This study aims to find out the language variation of the Indonesian tourist guide. This can provide readers with knowledge about the linguistic features of the Indonesian tourist guides who are the samples in this study.

Discussing English particular terms is quite aboard. As a result, the author selected a specific subtopic for the English variation. The English variants to be studied are restricted to a few segmental and expressional features. These segmental characteristics of English variation are discussed in some aspects; namely, 1) standard and non-standard English, 2) style and register, 3) code choice, 4) code-switching and codemixing, 5) grammatical, 6) omission and 7) Repetition

The outcome of this research is hoped to be highly beneficial to linguists in analyzing and developing new formulations in particular. Additionally, the author hopes that the study will contribute to English variation as a subject in universities and for foreign language users.

Language varies according to the social group, situation, and location. Variation demonstrates that no speaker speaks the same way all the time. Hudson (1980, p. 24) defines variety of language as a collection of linguistic items with a similar distribution that includes the following: English, French, London English, and the English used in football commentary are all dialects of the English language. Additionally, the definition enables us to 'treat all languages spoken by a multilingual speaker or community as a single variety, because all linguistic items in question have a similar social distribution.' Additionally, Finegan (2008) asserts that language varieties demonstrate the speakers' distinction from members of other groups. The variety of language that denotes specific situations of use is referred to as registers; it is appropriate for use in specific speech situations. According to Akmajian (1998), there are several 
types of language variations that are of interest to linguists: lingua francas, pidgins, creoles, jargon, slang, and taboo language.

These definitions are inclusive in that they permit us to refer to both an entire language and any specific type of linguistic usage associated with a particular region or social group as a variety. Each community, whether bilingual or multilingual, will have its own distinct flavor.

The following describes an explanation of the aspects that will be seen in analyzing the data

\section{Standard and Non-Standard English}

Language varieties can be classified as standard or non-standard. A language's standard variety includes both formal and informal or colloquial varieties (Trudgil, 2000)

Additionally, the term "standardization" refers to the process of formally codifying a language. This is typically accomplished through the development of grammars and dictionaries, as well as possibly literature.

Moreover, Widarso (1994) noted that ain't is the most prevalent non-standard English word, and the use of double negatives is also common in non-standard English. As a case study, here are the differences:

\section{Non-Standard English}

Jessie ain't been here. Jessie hasn't been here.

\section{Standard English}

We ain't going nowhere. We aren't going anywhere.
The first instance of Non-Standard English is demonstrated by the use of the word ain't; it is the most non-standard English word. In comparison, Standard English omits the term ain't in favor of hasn't.

The second example of Non-Standard English demonstrates the simultaneous use of the words ain't and no. As Holmes indicated, it falls within the category of the double negative, and this grammatical element deviates significantly from the conventional rule. The words ain't, and no are replaced by the words aren't and any in Standard English.

Standardization is, of course, a process that seeks to reduce or eliminate diversity and variety.

\section{Styles and Register}

The study of dialects is complicated by the fact that a speaker can pick from a range of different modes of speech. We can speak very officially or quite casually, depending on the situation. A formal speech is nearly always necessary during ceremonial events, but a more informal address is required for public speakers and informal conversations between close friends and family members. For instance, the sort of event, the social, age, and other disparities among participants; the activity at hand, such as writing or speaking; and the emotional engagement of one or more participants can all have an effect on the level of formality.

Our appreciation for stylistic appropriateness of What do you intend to do, 
your majesty? shows that such distinctions exist. That's not even taking into account Rex's question, "Want to do something?" A wide range of stylistic varieties can be demonstrated by native speakers across all languages despite the difficulty in distinguishing discrete levels of formality. With some degree of certainty, you can predict what style features a native speaker will use on a given occasion.

In the study of language variants, registers are a further complication that must be taken into account. People in society speak a variety of languages. For example, the doctor and the teacher speak very different languages. In Sociolinguistics, the term Register refers to the features of each of them. Groups of people having a common interest or employment, or the language used in situations linked with such groups, are all examples of registers. Each language's differences are tied to the situational context, which includes the field, mode, and tenor.

\section{Code Choice}

People use code as a means of communicating with each other. As a result, people must utilize a specific code to describe their thoughts and feelings. Code, according to Wardhaugh (1998), is any technique of communication used by two or more people. We need to select a language that will allow us to communicate effectively with others. Choose a specific dialect, dialect, or accent to use. A code is a "symbol of nationality" those individuals use to talk or communicate in a particular language, dialect, register, accent, or style at different times and for different purposes. Stockwell (2002) supports this statement. So, it may be inferred that coding is a form of communication. Code is a variation of language that civilization uses for the purpose of corresponding with other individuals. A coding choice can be characterized as selecting a language based on one's ability to speak and write in more than one. Code choice is the decision to use a specific language or linguistic variant in a given context. While it's possible to communicate with others by using more than one code, it's more common for people to use one code while they're in specific places or with specific people for particular objectives (in other places and with other people) as Richard and Schmidt (2002) stated that code choice is often quite regular and its patterns can be investigated.

\section{Code-Switching and Code-Mixing}

\section{Code-Switching}

Switching languages can happen between turns of speakers, between utterances within a turn, or even during a single utterance in the same discourse (Milroy \& Muysken, 1995). Gumperz (1982) defined codeswitching as the juxtaposition of two separate grammatical systems or subsystems inside the same speech exchange. As defined by Myers-Scotton (1993a), codeswitching occurs when speakers of a matrix language use forms from an embedded language (or languages) within the course of a single discourse. In other words, those who are 
fluent in more than one language have the freedom to express themselves freely. To cover a lexical gap, such as a word in one of the codes they do not know, or for some other specific reason, they switch between languages or codes (Bassiouney, 2009).

\section{Code-Mixing}

When it comes to everyday communication, the symptom of code-mixing is frequent in society, and it is especially prevalent in Indonesian society. According to Astri and Fian (2020), blending linguistic types when conducting communication results in normal communication. Indonesians who identify as bilingual or multilingual are the ones who are responsible for this phenomenon. The ability to apply more than one language, according to Saputro in Wulandari (2016), is defined as "the ability to mix two or more codes in a language discourse" in which the interlocutors or the writers blend two or more codes.

Furthermore, according to Nababan in Yuliana (2015), code-mixing is the ability to go from one language to another inside the same phrase during dialogue, or within a comparable prepared text or verbally during the same utterance. It is consistent with the statements made by Jendra in Sumarsih (2014), who states that code-mixing is a linguistic phenomenon in which several languages are mixed together within a single clause.
As summarized by some experts, codemixing is the ability of someone to mix languages inside a conversation when dealing with another person, but their conversation remains in the same situation, and just the language is changed.

Furthermore, according to Wulandari (2016), the background of education, social life, culture, economy, and the environment influences people's decision to combine the languages they speak.

\section{Grammatical}

Grammar is the system of rules that govern the sounds, structures, and meanings of a language. Grammar is present in all languages, and each language has its own grammar (Beverly, 2007, p.1). The nature of language is discovered by pupils through grammar, according to Azar (2007), who states that language is composed of predictable patterns that enable us to understand what we say, read, hear, and write.

\section{Omission}

Omission of errors is a type of error that occurs when the learners still lack the form or grammar that is required to be included in the sentence, but the learners omit or delete it. Hikmah (2020) asserted that omission could be referred to as deletion in some cases. It is defined as the absence of one or more components that must be present in a sentence or speech to be considered complete. It occurs 
when a lexical item that should be there is either omitted or eliminated from the sentence.

\section{Repetition}

Word repetition can produce the same type of chain as pronouns, and there are some convincing reasons to favor it over pronouns in some situations. Because repetition is considered 'bad style' in the United Kingdom, mother-tongue English learners are discouraged from using it and are instead encouraged to use a technique known as 'elegant repetition,' which involves the use of synonyms or more general words or phrases to replace the word or phrase being repeated. As a result, rather than writing

\section{METHODS}

\section{Source of Data}

\section{Library Research}

This is the stage in which the researchers conduct research on the subject through reading literature. The researchers conduct extensive research into important theories, particularly theories of language variation. Following the reading and study of various theories, the writer finds it easier to identify and understand their subject matter.

\section{Field Research}

The researchers conducted two distinct sorts of activities in this section, namely data collecting and data analysis.

\section{Instrument of Research}

The researcher conducted this study using an instrument that assisted them in obtaining accurate data. The data collection instruments are recording and documenting. Through the use of a cell phone, recording is employed to capture tourist guide utterances. Additionally, the researcher stated that data is required to complete this investigation.

\section{Methods of Analyzing Data}

The researcher used the descriptive qualitative method to analyze the data after it had been collected. The procedure of analysis data is five steps as follows.

\section{Transcribing}

The data is transcribed into structured data and notes after collecting the data through recording. This method is used to make the next step, identifying, a lot easier.

\section{Identifying}

The data regarding the types of language variation employed by the tourist guide was discovered by the researcher. According to the transcription data of recording, the researchers thoroughly studied and examined the data.

\section{Classifying}

The kinds of language variation used by tourist guides are classified when working as a guide.

\section{Analyzing}

Data analysis to identify the frequency of occurrences of all sentence types, style and 
register analysis, grammatical, codeswitching and code-mixing analysis, style and register analysis, and grammatical analysis of the full dataset. This process is illustrated with some instances of utterances extracted from the data.

\section{Concluding}

In the next step, the data result of the analysis is concluded by the researchers

\section{ANALYSIS AND DISCUSSION}

\section{Transcript Analysis}

Three respondents were interviewed for this transcript. They are Indonesians who work as tourist guides.

\section{Tourist Guide}

\section{Transcript 1}

Context : The conversation between guide and the customer but actually this is the second trip, so they have met before. The customer comes from the United States of Amerika.

Guide : Yes, emm. So, where are we going to?

Customer : we are going to Tana Keke

Guide : nope the island's called Kodi Ngarang Keke, I am sorry, I meanto, I have to tell you that it's kodi Ngareng Keke,

Customer : oh yee

Guide : we are going to go to the island. It is Inhabitant Island, so no people are there, and it is 30 minutes from the Popza (kampung popsa Makassar).
Customer : how big is this island?

Guide : I never been there actually but my friend said when I've been searched on the internet. It's quite small, it's smaller that in Samalona island. It has a very good spot for snorkeling so it's gonna be exited.

Customer : so, I am not very good in snorkeling so what else can we do there beside snorkeling.

Guide : if you stay longer, you can watch the sunset and you can do fishing, and then you can grap to do snorkeling. I can be your snorkeling body.

Customer : okay, that's there. I won't drunk

Guide : yes, so don't ask that I can't swim

: I am going to wear the life jacket ...... How about if I go to the port to ask the boat

Customer : to arrange the rent and everything?

Guide : yes, ....

Customer : that's a good idea.... How much do you think it will be?

Guide : it's run 400.000 rupiahs

Customer : for how long? for a whole day or a half of the day or...

Guide : they said for return so they will wait us to the island and then we can ask them whenever weready to go.

Customer : .......ok. That's good......

: What time we will be leaving?

Guide : I think at 1 oh no no no maybe it little bit early because it's gonna be oneday and a little bit further long trip ....

Customer : okay, so maybe we prepare at 08.00

Guide : okay, let's make it 08.00 


\section{Standard English and Non-standard English}

- It has a very good spot for snorkeling so it's gonna be exited .... Should be It's going. because it is not standard language.

- Nope should be NO

\section{Grammatical Features}

- I mean to should be I mean....

- it's gonna be exited... should be it is going to be exiting ....

- it's smaller that in Samalona island.... Should be It's smaller than Samalona island

- it's run for 400.000 rupiahs should be it runs for $\mathbf{4 0 0 . 0 0 0 ~ r u p i a h s ~}$

\section{Code Choice}

Table 1. Code Choice Transcript 1

\begin{tabular}{lc}
\hline \multicolumn{1}{c}{ Sentences } & \multicolumn{1}{c}{$\begin{array}{c}\text { Code } \\
\text { Choice }\end{array}$} \\
\hline ...... been there actually & Actually \\
\hline $\begin{array}{l}\text { … and then you can grab to do } \\
\text { snorkeling }\end{array}$ & $\begin{array}{c}\text { And } \\
\text { then } \\
\text {..... island } \text { and then we can ask } \\
\text { them }\end{array}$ \\
\hline
\end{tabular}

\begin{tabular}{l}
\hline$\ldots . .$. so, where are we going to \\
.... good spot for snorkeling so \\
it'sgonna be exited. \\
yes, so don't ask that I can't swim
\end{tabular}

\section{Omission}

- Let's make it at $08.00 \ldots . . . \ln$ this sentence, the speaker omits a.m. but the two speakers understand about that

\section{Omission of Auxiliary Verb ....}

- We can ask them whenever we are ready to go should be we can ask them whenever we are ready to go

\section{Code-Switching and Code-Mixing}

It is 30 minutes from the Popza (kampung popsa Makassar).

\section{Transcript 2}

Context: this is the conversation between the guide and the customer from Malaysia.

Guide : There is a museum LAGA LIGO over there and also there. This is actually have already been renovated by the government recently, actually late of the last year, in December. So this is actually have already been renovated by the government.

Malaysian : What is place used for? What purpose lah?

Guide : the purpose to public like the people come and then sit on thegrass and then while chatting and stuff and stuff and then you canalso see theheritage story of Indonesia. This is what we can saythat this is the place for Benteng, fort Rotterdam, the place is tomaintain from the conqueror at the time, conqueror south Sulawesi.

Malaysian : Dutch or British?

Guide : Holand, Netherlands

Malaysian : oh Dutch

Guide : yes, Dutch

Malaysian : nice place

Guide : ya... so sometimes like this, you can say someone sit on the grass and then..but you can see also some souvenirs places out there, museum etc 


\section{Repetition}

- This is actually have already been renovated by the government recently, actually late of the last year, in December

So This is actually have already been renovated by the government

\section{Grammatical Features}

- The missing of 'to be'

The purpose to public should be the purpose is to public

- Subject and Verb-Agreement

There is a museum LAGA LIGO over there and also there

- The missing of Verb after Modal

You can also the heritage story of Indonesia should be you can also see or observe the heritage story of Indonesia.

- Frequently use of signal post "and then" the purpose to public like the people come and then sit on the grass and then while chatting and stuff and stuff and then you can also the heritage story of Indonesia

\section{Code Choice}

Table 2. Code Choice Transcript 2

\begin{tabular}{ll}
\hline \multicolumn{1}{c}{ Sentences } & $\begin{array}{c}\text { Code } \\
\text { Choice }\end{array}$ \\
\hline $\begin{array}{l}\text { This is actually have already been } \\
\text { renovated by the government } \\
\text { recently }\end{array}$ & \\
\cline { 1 - 1 } This is what we can say thatthis is & This is \\
the place for Benteng, fort & \\
Rotterdam & \\
\hline
\end{tabular}

\begin{tabular}{lc}
\hline \multicolumn{1}{c}{ Sentences } & \multicolumn{1}{c}{$\begin{array}{c}\text { Code } \\
\text { Choice }\end{array}$} \\
\hline $\begin{array}{l}\text { So this is actually have already } \\
\text { been renovated by the } \\
\text { government. }\end{array}$ & So \\
\cline { 1 - 1 } $\begin{array}{l}\text {... So sometimes like this } \\
\text { the people come and then sit on } \\
\text { the grass }\end{array}$ & $\begin{array}{l}\text { And } \\
\text { then } \\
\text { and then while chatting }\end{array}$ \\
\hline $\begin{array}{l}\text { and then you can also theheritage } \\
\text { story of Indonesia. }\end{array}$ & \\
\hline
\end{tabular}

\section{Code-Switching and code mixing} ....this is the place for Benteng, fort Rotterdam

\section{Transcript 3}

Context : the conversation between the guide and some customers from different country in a group.

Guide $\quad:$.... Now we are in the gate of Laga Ligo Museum......sir, could you please come closer? .....

Customer : We enter ...?

Guide : ya ya. this is Laga-ligo museum that I informed several minutes ago. Laga Ligo museum is one of the museums here entailed with some artifacts and story thing...

Customer : this is Dutch fort?

Guide : ya...ya...Dutch

Customer : How many years Dutch here?

Guide : During 300 years

: the participant... this is one of ancient script, the oldest script of Laga ligo. ....it is kind of Luwuk Letters.

Customer : it looks like Arabic 


\begin{abstract}
Guide : it looks like Arabic because there was a relation between Arabic. Arabic was firstly disseminated religion.... landed first in Luwuk so their script was presumably influenced by Arabic

\section{Customer : Lontara?}

Guide : no, it is not Lontara but different one.

Guide : it is a crown ...the crown used for the Kingdom. It made not from gold

Customer : from copper

Guide : ya... copper. This crown has been given for several kings already.And the last is like hundred years ago. They innate... they innate the crown only to the generations, like I am the king and I am gonna give it to my son.
\end{abstract}

\footnotetext{
Guide $\quad:$.... this is the king sword. made from the very tight steel meanwhile at the time.

Guide : this is one of the oldest Qur'an, holy book of Muslim. It is written by hand

Customer : oh really...?

Guide : ya..it is written by hand
}

\section{Standard and Non-Standard English}

I am gonna give it to my sonshould bel am going to give it to my son

\section{Grammatical Features}

a. Between and (the imperfect usage) (missing of'and')

- there was a relation between Arabic should be there was a relation between Arabic and Luwuk

\section{b. The missing of auxiliary verb}

- They innate should be they were innate

\section{c. Subject-Verb Agreement}

- Arabic was firstly disseminate religion should be Arabic was firstly disseminating religion

\section{d. Restructuring}

- It made not from gold should be it is not made from gold

- the crown used for the Kingdom should be the crown used by the king

\section{Code Choice}

Table 3. Code Choice Transcript 3

\begin{tabular}{lc}
\hline \multicolumn{1}{c}{ Sentences } & $\begin{array}{l}\text { Code } \\
\text { Choice }\end{array}$ \\
\cline { 1 - 1 } This is one of ancient script & \\
\cline { 1 - 1 } Th.this is the king sword.... & \\
\cline { 1 - 1 } ...this is one of the oldest Qur'an,.. & \\
\cline { 1 - 1 } $\begin{array}{l}\text { … landed first in Luwuk so their } \\
\text { script was presumably influenced } \\
\text { by Arabic... }\end{array}$ & So \\
\hline
\end{tabular}

Based on the findings, the writer gets that the three tourist guides have quite similar code choices between one and the other. They are using some particular lexical (actually, so, this is an 'and then'). From these results, we can see that basically tourist guides have code choices that are regularly used and are basically the same because when they explain a place to their customers, of course, they use the same words as "this is," "and then" etc. . This is in line with what Richard and Schmidt (2002) said that code 
choice is often quite regular and its patterns can be investigated

The analysis of this study shows that basically, the tourist guide performs codeswitching and code-mixing when providing detailed explanations to its customers who are people from foreign countries. This can be seen when the first Tourist Guide said "Kampung Popza Makassar," which can be seen from the following fragment of the conversation

Guide : we are going to go to the island. It is Inhabitant Island, so no people are there, and it is 30 minutes from the Popza (kampung popsa Makassar).

The word in bold above is an example of where the first tourist guide did code-switching and code-mixing. From the excerpt above, it can be seen that the tourist guide mentions the word popza twice, but when she mentions it the second time, the guide mentions the original name of the place. Here it appears that she wants to tell his customers how the place is called by the people around the area so that it can be more familiar if mentioned.

Moreover, the second tourist guide also performs code-switching and code-mixing, which can be seen from the following fragment of conversation

Guide :

This is what we can say that this is the place for Benteng, fort Rotterdam, the place is to maintain from the conqueror at the time, conqueror south Sulawesi.
From the excerpt of the conversation above, it can be seen that the guide said the word "benteng," which is a word that people around usually call the place, namely "Benteng Rotterdam."

From the two fragments of the conversation above, the researchers analyze that the guides do code-switching and codemixing because they want to give the real name of one place.

From the conversation fragment above, it can also be seen that language switching occurs during a single utterance in the same discourse, which is in line with what Milroy \& Muysken (1995) said that switching languages could happen between turns of speakers, between utterances within a turn or even during a single utterance in the same discourse.

\section{CONCLUSION}

The three-tourist guides have quite a similar code choice between one and the other. They are using some particular lexical, namely actually, so, this is and 'and then. Besides that, they also do code switching and code-mixing. The researchers analyzes that the tourist guides do code-switching and code-mixing because they want to give the real name of one place.

\section{REFERENCES}

Akmajian, A. (1998). Linguistics: An Introduction to Language and Communication. Massachusetts: MTT Press.

Astri, Z., \& Fian, A. (2020). The Sociolinguistics Study on the Use of Code Mixing In Gita Savitri Devi's Youtube Channel 
Video. SELTICS,

83-92.

https://doi.org/10.46918/seltics.v0i0.728

Azar, B. (2007). Grammar-based teaching. A Practitioners' perspective. TESL-EJ, 11(2). Retrieved July 30, 2013, from http://teslej.org/ej42/a1.htm

Bassiouney, R. (2009). Arabic sociolinguistics. Edinburgh: Edinburgh University Press.

Beverly, A. H. (2007). The Role of Grammar in Improving Students' Writing. Retrieved on October 30, 2021, from http://www.sadlieroxford.com/docs/lang uage/paper_chin.cfm

Gumperz, J.J. (1982). Discourse Strategies. Cambridge: Cambridge University Press.

Hikmah, Harisna. (2020). Analysis of Omission and Addition Errors Found in the Students' English Texts. ELTICS (English Language Teaching and English Linguistics) Journal 5(1), January 2020 ISSN: 2407-0742

Holmes, Janet. (1992). An Introduction to Sociolinguistics. UK: Longman Group Ltd.

Kisno. (2011). The Greates flix : A Friendly
Approach. University of Leeds. United Kingdom.

Milroy, L., \& Muysken, P. (1995). One speaker, Two languages: Cross-Disciplinary perspectives on codeswitching. Cambridge: Cambridge University Press.

Mulyadi. (2009). Introduction to Linguistics. Pamekasan: STAIN Pamekasan Press.

Myers-Scotton, C. (1993a). Social motivations for Code-switching: Evidence from Africa. Oxford: Clarendon Press.

Richard, Jack and Richard Schmidt. (2002) Longman Dictionary of Language Teaching and Applied Linguistics. London: Person Edication Limited.

Stockwell. (2002). Sociolinguistics: A Resource Book for Students. London: Rutledge.

Sumarsih. (2014). Code Switching and Code Mixing in Indonesia: Study in Sociolinguistics. English Language and Literature Studies, Volume 4, No 1, 2, p. 79.

Trudgill, Peter. (2000). Sociolinguistics: An Introduction. Great Britain: Pelican Books. 